\title{
Climate change impacts on freshwater fish, coral reefs, and related ecosystem services in the United States
}

\author{
Diana Lane • Russell Jones • David Mills • \\ Cameron Wobus • Richard C. Ready • \\ Robert W. Buddemeier • Eric English • \\ Jeremy Martinich • Kate Shouse $\cdot$ Heather Hosterman
}

Received: 31 January 2013 / Accepted: 20 February 2014 / Published online: 5 April 2014

(C) The Author(s) 2014. This article is published with open access at Springerlink.com

\begin{abstract}
We analyzed the potential physical and economic impacts of climate change on freshwater fisheries and coral reefs in the United States, examining a reference case and two policy scenarios that limit global greenhouse gas (GHG) emissions. We modeled shifts in suitable habitat for three freshwater fish guilds and changes in coral reef cover for three regions. We estimated resulting economic impacts from projected changes in recreational fishing and changes in recreational use of coral reefs. In general, coldwater fisheries are projected to be replaced by less desirable fisheries over the 21 st century, but these impacts are reduced under the GHG mitigation scenarios. Similarly, coral cover is projected to decline over the 21 st century primarily due to multiple bleaching events, but the GHG mitigation scenarios delay these declines in Hawaii (but not in South Florida or Puerto Rico). Using a benefit-transfer approach, we estimated that global policies limiting GHG emissions would
\end{abstract}

This article is part of a Special Issue on "A Multi-Model Framework to Achieve Consistent Evaluation of Climate Change Impacts in the United States" edited by Jeremy Martinich, John Reilly, Stephanie Waldhoff, Marcus Sarofim, and James McFarland.

Electronic supplementary material The online version of this article (doi:10.1007/s10584-014-1107-2) contains supplementary material, which is available to authorized users.

D. Lane $(\bowtie) \cdot$ R. Jones $\cdot$ D. Mills $\cdot$ C. Wobus $\cdot$ E. English $\cdot$ H. Hosterman

Stratus Consulting Inc., 1881 Ninth Street, Suite 201, Boulder, CO 80302, USA

e-mail: dlane@stratusconsulting.com

R. C. Ready

Department of Agricultural Economics and Rural Sociology, The Pennsylvania State University, University Park, PA, USA

R. W. Buddemeier

Kansas Geological Survey, Lawrence, KS, USA

J. Martinich $\cdot$ K. Shouse

Climate Change Division (6207-J), U.S. Environmental Protection Agency, Washington, DC, USA 
provide economic benefits in the range of \$10-28 billion over the 21 st century through maintaining higher values for recreational services for all freshwater fisheries and coral reefs, compared to the reference scenario. These economic values are a subset of the total economic and societal benefits associated with avoiding projected future declines in freshwater fisheries and coral reef cover due to unmitigated climate change.

\section{Introduction}

Anthropogenic greenhouse gas (GHG) emissions and the resulting changes in climate projected to occur through the 21 st century threaten the health of aquatic resources and the ecosystem services they provide in the United States (U.S.). While there has been extensive analysis of potential biophysical impacts of climate change, a consistent national-scale analysis of climate change impacts and economic damages across sectors has been lacking and is the goal of the Climate Change Impacts and Risk Analysis (CIRA) project (Waldhoff et al. 2014, this issue). Within the CIRA framework, we address two categories of aquatic resources in the U.S. with significant recreational use: freshwater fish habitat and coral reefs. We selected these aquatic resource categories because data and models are available that can relate climatic changes to biophysical impacts and resulting economic losses. Because our scope is limited to two resource categories, the economic losses presented here are a subset of the likely total economic impacts to aquatic resources in the U.S. caused by anthropogenic GHG emissions.

Within the coterminous U.S., higher air temperatures, along with changes in precipitation, are anticipated to alter future streamflow and fish habitat. Impacts include alterations in the thermal suitability of U.S. streams for freshwater fish and changes in regional hydrology (Bates et al. 2008). Offshore, the combined effects of elevated sea-surface temperatures and rising atmospheric carbon dioxide $\left(\mathrm{CO}_{2}\right)$ levels increase the risk of coral bleaching and decrease coral growth rates. Thus, climate change is projected to affect the viability of coral reef ecosystems (Smith and Buddemeier 1992; Hoegh-Guldberg et al. 2007; Donner 2009).

Climate change impacts to freshwater fish habitats and coral reefs could result in a significant loss of value associated with the diverse ecosystem services these habitats provide, including tourism, commercial harvest, and existence (i.e., non-use values). In this analysis, we focus on recreational services and have not quantified losses to other services. For freshwater fish habitats, we focus only on a decline in the value of recreational fishing in streams and rivers in the coterminous U.S., which is just one component of potential loss. We rely on a model developed by Vaughan and Russell (1982) to project the economic impacts of habitat changes on recreational fishing in the U.S. Similarly, for coral reef habitats, we estimate declines in economic values for recreational services from coral reefs associated with climate-induced declines in coral reef cover in Hawaii, Florida, and Puerto Rico. We use a benefits-transfer approach to estimate economic values for recreational services from coral reefs using previously published estimates from studies conducted at a range of coral reef sites.

The objective of this paper is to quantify biophysical and economic risks of climate change associated with impacts to freshwater fish and coral reef ecosystems and the recreational use of these resources, within the consistent, multi-sector CIRA modeling framework (Waldhoff et al. 2014, this issue). By estimating future impacts under several emissions scenarios and climate sensitivities, and quantifying the lost economic value of ecosystem services provided, this paper provides information on some of the risks of climate change relevant for the development of climate policies. The results also provide a perspective on how the different compo- 
nents of climate change (e.g., temperature increases, precipitation changes, increases in atmospheric $\mathrm{CO}_{2}$ ) interact with ecological factors and organismal biology to generate distinctive, non-linear, and specific impacts to ecosystem function and service values that vary spatially.

\section{Methods}

\subsection{Emissions scenarios and climate projections}

The framework and simulations used to project future climate, using the Integrated Global Systems Model linked with the Community Atmospheric Model (IGSM-CAM), are presented in Monier et al. (2014, this issue). Three emissions scenarios are used: the reference (REF) or "business-as-usual" case, and two scenarios representing futures with GHG mitigation policies that limit global emissions such that radiative forcing levels in 2100 are stabilized at $4.5 \mathrm{~W} / \mathrm{m}^{2}$ (POL4.5) or $3.7 \mathrm{~W} / \mathrm{m}^{2}$ (POL3.7). ${ }^{1}$ Detailed descriptions of these scenarios are given in Paltsev et al. (2014, this issue).

Since the IGSM-CAM model represents a single general circulation model (GCM) pattern, we employed simplified representations of GCM patterns within a sensitivity analysis to examine structural uncertainties associated with climate model selection. We used two additional GCM patterns to produce a range of precipitation futures for the REF and POL3.7 scenarios for the fisheries model only: the Model for Interdisciplinary Research on Climate (MIROC 3.2-medres) projects a relatively hot/dry future and the Community Climate System Model (CCSM 3.0) projects a relatively cool/wet future. The coral model does not use precipitation as an input, so it was excluded from this sensitivity analysis. Monier et al. (2014, this issue) describes how these projections compare to the IGSM-CAM simulations. Finally, we used climate sensitivity values of 3 and $6{ }^{\circ} \mathrm{C}$ as part of a sensitivity analysis for the results presented here. ${ }^{2}$

\subsection{Fisheries modeling}

Our objective for the fisheries modeling is to project physical and economic impacts of climate change on freshwater fisheries at a national scale. The modeling approach is outlined briefly below; further details are provided in Jones et al. (2012).

To model changes in fish habitat suitability in response to projected climate changes, we classify streams within a modeled polygon ${ }^{3}$ according to their thermal suitability for a coldwater, cool/warmwater, or highly thermally tolerant, lower recreational priority (i.e., "rough") fish guild (Eaton and Scheller 1996). For simplicity, we refer to these guilds as "coldwater," "warmwater," and "rough." The maximum thermal threshold for each guild is

\footnotetext{
${ }^{1}$ As such, the POL3.7 scenario (500 ppm of $\mathrm{CO}_{2}$-equivalent, for all Intergovernmental Panel on Climate Change gases, in 2100) is slightly more stringent than the POL4.5 scenario (600 ppm). Under the REF scenario, GHG concentrations reach $1,750 \mathrm{ppm}$, and the total radiative forcing is $10 \mathrm{~W} / \mathrm{m}^{2}$.

${ }^{2}$ Climate sensitivity is the assumed change in global mean temperature (e.g., $3{ }^{\circ} \mathrm{C}$ ) under a doubling of $\mathrm{CO}_{2}$ concentration. The results presented in the main text and figures of this paper all use climate sensitivity values of $3{ }^{\circ} \mathrm{C}$.

${ }^{3}$ The analysis is conducted using a spatially explicit modeling framework of grid cells organized into 2,099 eight-digit hydrologic unit code (HUC) polygons for the coterminous U.S.
} 
based on the water temperature tolerance for each guild's most tolerant species: coldwaterbrown trout (Salmo trutta), warmwater-smallmouth bass (Micropterus dolomieu), and rough - channel catfish (Ictalurus punctatus) [see 95th-percentile upper temperature threshold in Eaton et al. (1995) and Eaton and Scheller (1996)]. Thermal suitability is based on regionspecific regressions of air temperature and water temperature developed from stream gauge data reasonably free of the influence of non-climatic factors.

Because the model is based on region-specific temperature regressions, our study implicitly assumes no barriers to fish movement or occupation of suitable habitat. We assume a best-case scenario in which any area of thermal refugia within a HUC (i.e., even a single modeled cell value) will continue to keep that HUC suitable for the relevant guild, even though fish may not be able to migrate to suitable habitat as climate conditions change (Tonn 1990). Thus, our model is more likely to underestimate climate change impacts to fisheries than overestimate.

We use simulated changes in monthly runoff, as derived from the Climate and Runoff (CLIRUN) model [see Strzepek et al. (2014, this issue)], to calculate changes in river habitat area (i.e., area of water within the stream) assuming a relationship between average discharge and average width (Dunne and Leopold 1978; Allen et al. 1994; see Online Resource 1 for additional calculation details). We then sum the total suitable acres by fish guild and state.

Results from the fish habitat modeling serve as input to an economic model to analyze the impacts of climate change on the value of U.S. recreational fishing. Specifically, we updated a model developed by Russell and Vaughan (1982) and Vaughan and Russell (1982) that estimates the total number of freshwater recreational fishing days in rivers and streams in the coterminous U.S. based on the availability of fishing habitat, catch rates, and state-level demographic variables. The model estimates the likelihood that an adult in a particular state is an angler and the likelihood that an angler fishes for species in each guild. The model then estimates the number of fishing days for each guild and applies relevant per-day economic values. These economic values are based on estimates of consumer surplus, which is defined here as the maximum additional amount of money recreationists would be willing to pay for a day of fishing, above the actual cost. Coldwater days are valued at $\$ 59.74$, warmwater days at $\$ 39.31$, and rough fishing days at \$31.04 [Jones et al. (2012), with values adjusted to 2005\$; see Online Resource 2 for derivation].

Changes in economic value are projected using 30-year habitat averages centered at 2050 and 2100 for each climate scenario. We account for projected increases in human population growth over the 21 st century (see Online Resource 3 for projection methods) - these projections are kept constant across the GHG emissions scenarios. However, we do not model any projected changes in fish populations independent of habitat changes because of the complexity of site-specific conditions and stocking that affect fish populations. Values are adjusted to present value, using a $3 \%$ discount rate and a base year of 2015 , consistent with the other papers on this issue.

\subsection{Coral reef modeling}

Our coral reef modeling objective is to project the physical and economic impacts of climate change on coral reefs in Hawaii, South Florida, and Puerto Rico, which are three key coral reef regions in U.S. territorial waters. We use a modified version of the COMBO (Coral Mortality and Bleaching Output) model, which integrates thermal and ocean chemistry effects of future climate change on coral growth and mortality, to estimate changes in coral cover over time in different locations (see Buddemeier et al. 2008, 2011 for technical details). We also develop and apply a conceptual framework for assessing how economic values might decline as coral cover is lost, resulting in estimates of the total present value of economic losses to coral reefs in the three locations from 2000 to 2100 for the three GHG emissions scenarios. 


\subsubsection{Changes in coral reef cover}

Changes in sea surface temperature (SST) and atmospheric $\mathrm{CO}_{2}$ in the COMBO model are driven by the IGSM-CAM projections, which results in long-term changes in coral growth and decay due to average changes in SST and carbonate equilibrium chemistry. The COMBO model also simulates episodic bleaching events that cause widespread coral mortality. This component of the model generates bleaching and resulting mortality when projected temperatures exceed thresholds established from observations of heat doses leading to historical bleaching events. We used existing datasets as our source for baseline coral cover data (see Buddemeier et al. 2008, 2011); the 90th percentile coral cover value within a $1^{\circ}$ cell is used as that cell's baseline coral cover value to represent favorable conditions (avoiding the potential bias that "reefs at risk" may be more likely to be studied than healthy reefs). For each emissions scenario, changes in coral cover through time are calculated for each $1^{\circ}$ cell in all three regions and applied to the baseline coral cover value. Cover values are then averaged across cells to develop regional plots of changes in percent cover through time.

\subsubsection{Economic analysis of coral reef cover loss}

The most recognizable use values generated by coral reefs are the benefits enjoyed by people who visit reefs for recreation. As in the fish modeling, we use consumer surplus as our measure of use value for reef-based recreation. Here, consumer surplus represents the net benefit to the recreationist of engaging in a reef visit instead of an alternate activity. To generate values for this study, we take a "benefit-transfer" approach, where benefit estimates measured in one area are used to value benefits enjoyed in a different area (Shrestha and Loomis 2001; LondonoDiaz and Johnston 2012). We limit our benefit-transfer analysis to studies conducted in the U.S. and its territories that specifically measured consumer surplus for reef-related recreation. We use the average value [and a $95 \%$ confidence interval (CI)] from all studies reviewed, $\$ 104.96$ (\$54.57, \$155.35) in 2005\$, as our measure of consumer surplus for a recreational visit to a coral reef [see Lane et al. (2013) and Online Resource 4 for additional details on our approach and why we select an average value]. This is multiplied by estimates of the total number of reef visits in Hawaii (Cesar et al. 2002), Puerto Rico (Estudios Técnicos 2007), and Florida (Johns et al. 2001) to estimate recreational use values in each location (see Online Resource 5). In Puerto Rico, there is no available estimate of nonresident reef visits. Thus, the estimates presented here for Puerto Rico should be considered as an initial, lower-bound estimate; data on nonresident tourist visits to reefs are needed to develop a more comprehensive estimate for Puerto Rico consistent with the other locations.

For recreation in general, and reef recreation in particular, there is uncertainty about the complex relationship between climate change impacts and recreation behavior (Gössling et al. 2012). Complete loss of coral reefs would result in a complete loss of reef-related recreation. However, for intermediate levels of reef loss, the relationship between coral cover and recreational use (e.g., reef visits) is unknown. Studies have found that reef condition is important to recreational users (Gössling et al. 2012), but differ on whether there is a threshold relationship where the frequency of reef visits is insensitive to coral reef health as long as reef conditions are above a minimum level (Gössling et al. 2006), or a proportional relationship between coral cover decline and measures of recreational value such as reef visitation (Kragt et al. 2009) or consumer surplus (Bhat 2003). Kragt et al. (2009) asked divers and snorkelers who had visited the Great Barrier Reef how their future trips would change if the reef changed to a degraded state with an $80 \%$ decline in coral cover, a $70 \%$ decline in fish diversity, and a $30 \%$ decline in coral diversity. This contingent behavior study found that there could be an 
$80 \%$ decline in future trips, from a mean of 2.82 trips to 0.56 trips. We chose to employ a proportional relationship between coral cover and recreational visits for two reasons. First, it is a parsimonious choice given the uncertainty of the shape of this relationship. Second, it is consistent with the Kragt et al. (2009) survey, the study most directly relevant to our climate change impacts analysis. If the true relationship between reef cover and recreational value is nonlinear, then this assumption could overstate the loss in recreational values for intermediate levels of coral reef loss.

The economic benefits, or avoided impacts, of GHG mitigation policies are calculated from the difference between total recreational visits under the mitigation scenarios versus the REF scenario, assuming a direct linear relationship between coral cover ${ }^{4}$ and the number of recreational visits, as described above. As with the fisheries modeling, the number of recreational visits is adjusted by applying regional population growth estimates for each region through time and assuming that recreational visits change in proportion to population change (see Online Resource 3 for details on modeling population change). We translate these changes in recreational visits into dollars by integrating the annual present value of lost recreational visits over the 21 st century, using a $3 \%$ discount rate and a 2015 base year.

\section{Results}

\subsection{Fisheries}

\subsubsection{Thermal suitability of waters}

Across all three emissions scenarios for the IGSM-CAM, the spatial distribution of suitable habitat for coldwater fisheries is projected to diminish over the 21 st century (Fig. 1). Considering the thermal modeling only, a projected $62 \%$ loss in coldwater fishery habitat under the REF scenario (approximately 440,000 acres lost) is reduced to a $16 \%$ loss (approximately 115,000 acres) under the POL3.7 scenario. By 2100, rough fisheries are projected to increase by approximately 220,000 acres under the REF scenario compared to current conditions, but would be limited to an increase of approximately 13,000 acres under the POL3.7 scenario (see Online Resource 6 for detailed results tables).

On a regional basis, by 2100 , the REF scenario projects that coldwater fisheries are limited almost exclusively to the mountainous areas of the West and have disappeared from Appalachia, while substantial portions of Texas, Oklahoma, Kansas, Arizona, and Florida are converted from warmwater to rough species. While it is theoretically possible for guild shifts to "skip" a guild (e.g., shift from cold to rough), in all cases of our model output, shifts between habitat guilds passed from cold to warm and then to rough.

The habitat shift from coldwater to warmwater fisheries is projected to be much less prevalent under the two GHG mitigation scenarios. By 2100, coldwater fisheries are projected to remain in Appalachia under both mitigation scenarios, although reduced by roughly $50 \%$ compared to current conditions. Coldwater fisheries are also projected to remain in the vast majority of the West with the exception of the desert Southwest. Lastly, we see almost no shifts

\footnotetext{
${ }^{4}$ Because available coral reef cover data are not evenly distributed across each region, we calculate a weighted average of coral reef decline for each region (using the relative amount of ocean hardground area in each $1 \times 1^{\circ}$ grid cell for weighting) for use in the valuation calculations. Ocean hardground area was obtained from Smith and Sandwell (1997) and serve as approximations of areas suitable for coral reef establishment. This method was used to construct a regional estimate of coral reef decline instead of averaging data from individual cover estimates in point locations.
} 

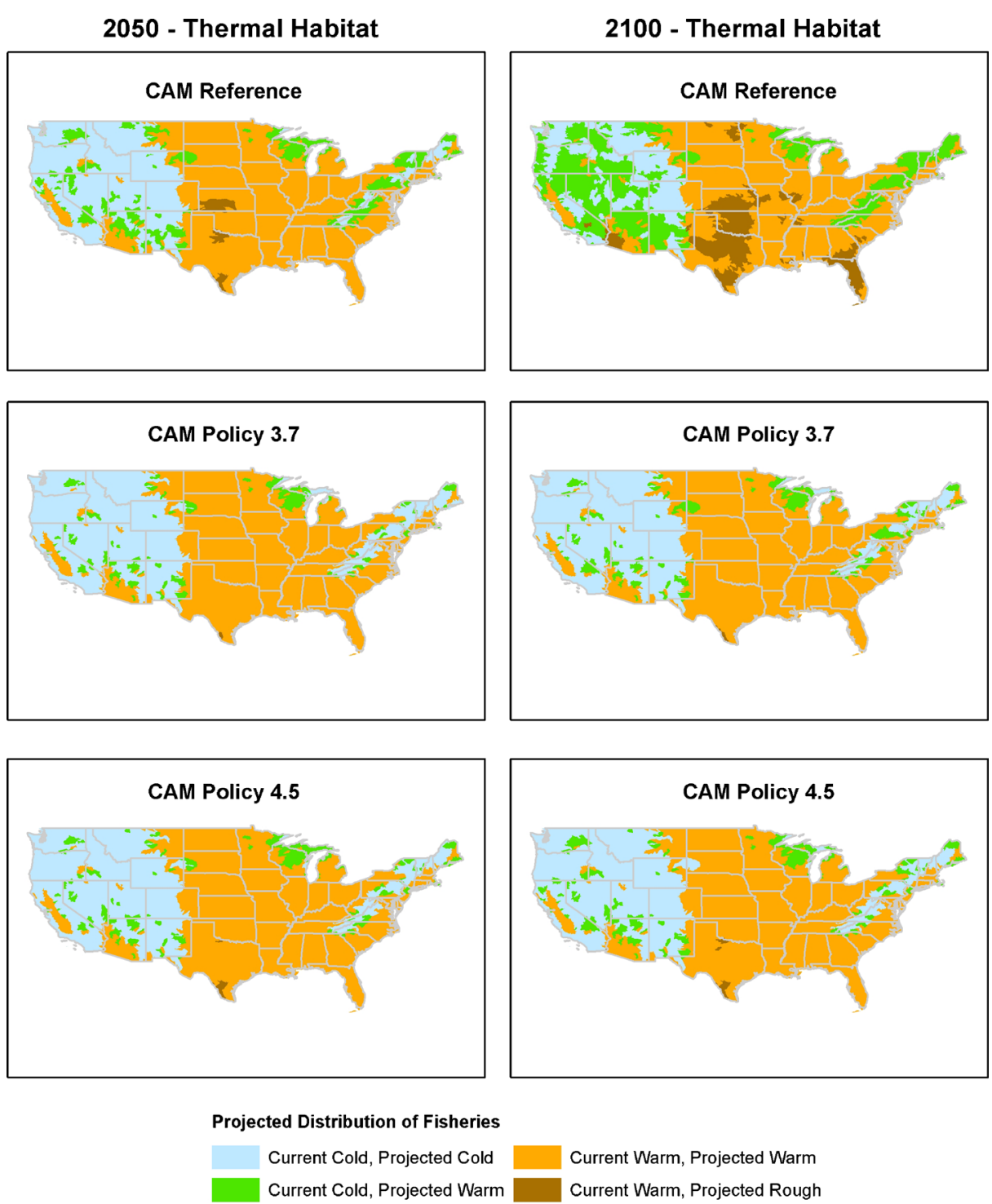

Current Warm, Projected Warm

Current Warm, Projected Rough

Fig. 1 Projected change in distribution of coldwater, cool/warmwater, and rough fish guilds by 2050 and 2100 for REF, POL3.7, and POL4.5 climate scenarios. Results are shown under a $3{ }^{\circ} \mathrm{C}$ climate sensitivity

from warm to rough fisheries in either mitigation scenario, except for small pockets in Texas under POL4.5.

\subsubsection{Changes in stream flow}

Overall under the REF scenario, the general pattern of projected change in stream flow by 2100 is as follows: in the West/Southwest, watersheds are projected to become drier; in the 
middle of the country, watersheds are projected to become progressively wetter to extremely wet ( $>200 \%$ of historical flows); along the East Coast, watersheds are projected to become increasingly wetter (up to a 50-100 \% increase). The same basic, but more muted trends, are projected to occur by 2050 , although some watersheds in the middle of the country are drier in 2050 compared to historical conditions but wetter in 2100 (Fig. 2).

Under both GHG mitigation scenarios, the same general pattern is projected as in the REF scenario, but the magnitude and rate of changes are smaller (Fig. 2). Both mitigation scenarios project a substantial drying in California and in the southern Rocky Mountains and wetter
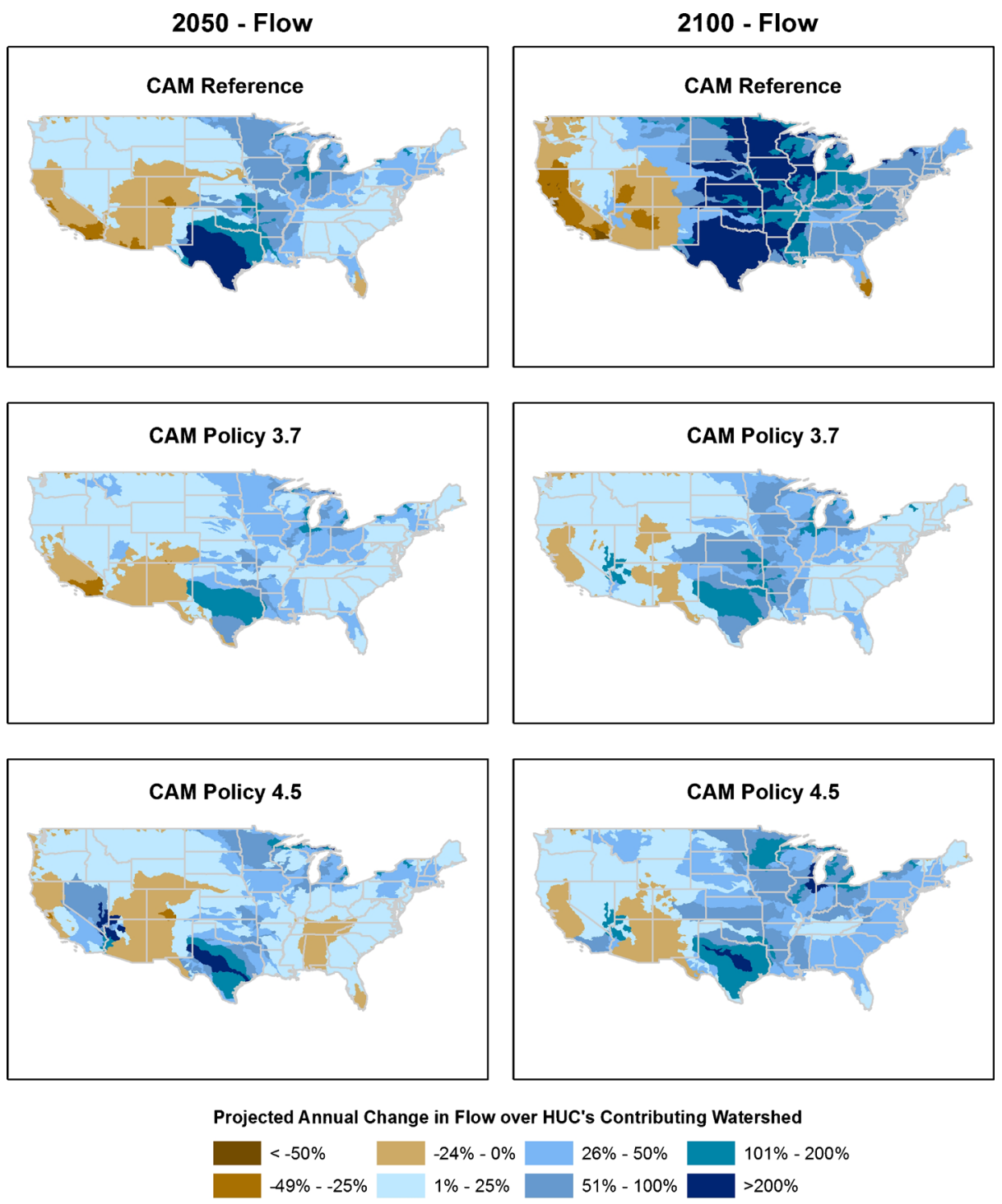

Fig. 2 Projected annual change in stream flow in 2050 and 2100 for REF, POL3.7, and POL4.5 climate scenarios. Results are shown under a $3^{\circ} \mathrm{C}$ climate sensitivity 
conditions in the middle of the country, including Texas. A distinct difference from the REF scenario is that neither of the two policy scenarios project drier conditions in the Pacific Northwest by 2100 .

We examined the sensitivity of results to a doubling of climate sensitivity, comparing model runs assuming a $3{ }^{\circ} \mathrm{C}$ climate sensitivity to results assuming a $6{ }^{\circ} \mathrm{C}$ sensitivity (using results for 2100 for the POL3.7 scenario for the IGSM-CAM; see Online Resource 7). Under a $6{ }^{\circ} \mathrm{C}$ sensitivity, we found thermal habitat changing from colder to warmer guilds west of the Rocky Mountains and in southern Texas. However, we found counter-intuitive results in a few areas in Appalachia and along the Wyoming/South Dakota border, where the $6{ }^{\circ} \mathrm{C}$ sensitivity model runs projected habitat remaining thermally suitable for coldwater fish while the $3{ }^{\circ} \mathrm{C}$ sensitivity runs projected a shift to warmwater fish. These counter-intuitive results illustrate the non-linear, spatial complexity inherent in the IGSM-CAM.

We also compared the IGSM-CAM results for thermal and flow changes with those from the IGSM pattern-scaled models: MIROC and $\mathrm{CCSM}^{5}$ [see Online Resource 8 and Monier et al. (2014, this issue) for a detailed comparison]. There is a striking difference between the models for flow variables, but smaller differences for thermal habitat - an expected result, as GCMs are in more agreement regarding the magnitude of regional temperature change compared to precipitation. The majority of the country is projected to have higher flows in the IGSM-CAM (ranging from 1 to $25 \%$ in most of the eastern and western U.S., and from 26 to $200 \%$ in the Midwest). In contrast, there are only small increases in flow projected for the northern half of the U.S. under the relatively cool-wet CCSM, and the relatively hot/dry MIROC projects decreases in flow across almost the entire U.S. by 2100. These results show the high degree of variability across GCMs for precipitation variables, and especially the wet nature of the IGSM-CAM.

\subsubsection{Economic results}

Under the REF scenario, the total annual number of all recreational fishing days is projected to increase from 2011 to 2050 by approximately 1,500,000 days, but then decline in 2100 to approximately the same level as 2000 . For both GHG mitigation scenarios, there is a projected annual gain of approximately 700,000 days by 2100 for all fishing types and approximately 2,700,000 days for coldwater fishing, relative to the REF scenario (see Online Resource 9 for a detailed table).

The fishing value for each guild is derived by multiplying the number of fishing days by the value of a fishing trip. The annual projected value of recreational fishing is approximately equal across the REF and two GHG mitigation scenarios for 2011-2050, but then declines for the REF scenario for 2050-2100 (see Online Resource 10 for an annual values figure). As shown in Table 1, the greatest recreational benefits, i.e., reduced damages under the POL3.7 scenario compared to the REF scenario-are associated with coldwater fishing, with a net present value of $\sim \$ 1$ billion. When all fishing is considered, the net present value of recreational benefits is approximately $\$ 300$ million

\footnotetext{
${ }^{5}$ Waldhoff et al. (2014, this issue) provide a detailed discussion of the motivation and rationale behind the climate model selection (IGSM-CAM combined with sensitivity analysis using the scaled patterns). In short, using a single climate model allows for the reasonable exploration of important uncertainty sources (e.g., emissions, climate sensitivity, natural variability).
} 
for the POL3.7 scenario, reflecting losses in coldwater fishing days and gains in other types of fishing.

\subsection{Coral reefs}

In all three modeled regions, the two mitigation scenarios in the IGSM-CAM (POL3.7 and POL4.5) limit the rate and magnitude of long-term rises in SST. Although the mitigation scenarios decrease total SST rise at all sites, projected benefits are region-specific. For example, while coral reef cover trajectories are significantly different for the mitigation and REF scenarios in Hawaii, the trajectories are very similar for Florida and Puerto Rico, where present-day temperatures are already close to bleaching thresholds (Fig. 3). All these results assumed a $3{ }^{\circ} \mathrm{C}$ climate sensitivity.

We also examined the sensitivity of the coral reef results to different modeling assumptions. The $6{ }^{\circ} \mathrm{C}$ sensitivity greatly reduces the benefit of the POL3.7 scenario in Hawaii, compared to the $3{ }^{\circ} \mathrm{C}$ sensitivity. Using the $6{ }^{\circ} \mathrm{C}$ sensitivity, both the REF and POL 3.7 scenarios project coral cover to drop below $5 \%$ by 2060 (see Online Resource 11).

As shown in Table 1, the greatest recreational benefits (i.e., reduced damages under the POL3.7 scenario compared to the REF scenario) are in Hawaii, with an average net present value of $\sim \$ 17$ billion (95\% CI of $\$ 9-26$ billion). The net present value of recreational benefits is positive but notably lower in Florida ( $\$ 1.3$ billion; $95 \%$ CI of \$0.7-2.0 billion) where coral reefs are already close to bleaching thresholds. The estimate of recreational benefits under the POL3.7 scenario in Puerto Rico $(\sim \$ 0.4$ million, $95 \% \mathrm{CI}$ of $\$ 0.2-0.5$ million) is a lower-bound estimate for residents only that is not comparable to the other locations where nonresident tourist visits to reefs are also included. This value serves primarily to indicate that recreational benefits are likely in Puerto Rico under a reduced GHG mitigation scenario.

Table 1 Increase in total future value of recreational fishing and coral reef visitation from 2011 to 2100 for the POL3.7 and POL4.5 scenarios compared to the REF scenario (millions 2005\$)

$\begin{array}{lll}\text { Recreational freshwater fishing analysis } & & \\ & \text { POL3.7 } & \text { POL4.5 } \\ \text { Temperature and precipitation climate change scenario } & \\ \quad \text { All fishing } & \$ 324 & \$ 193 \\ \quad \text { Coldwater fishing only } & \$ 1,236 & \$ 1,068 \\ \text { Temperature only climate change scenario } & & \\ \quad \text { All fishing } & \$ 217 & \$ 168 \\ \quad \text { Coldwater fishing only } & \$ 1,058 & \$ 875 \\ & & \\ \text { Coral reef recreation analysis } & & \text { POL4.5 } \\ \text { Region } & \$ 1,319(686 ; 1,953) & \$ 2,186(1,136 ; 3,236) \\ \text { South Florida } & \$ 0.36(0.18 ; 0.52) & \$ 0.30(0.16 ; 0.44) \\ \text { Puerto Rico } & \$ 17,443(9,067 ; 25,819) & \$ 11,493(5,974 ; 17,012)\end{array}$

Dollars are discounted to present-value terms with a base year of 2015 and a $3 \%$ discount rate. For the coral reef analysis, the range provided is a $95 \% \mathrm{CI}$, based on the $95 \% \mathrm{CI}$ for per-trip values 

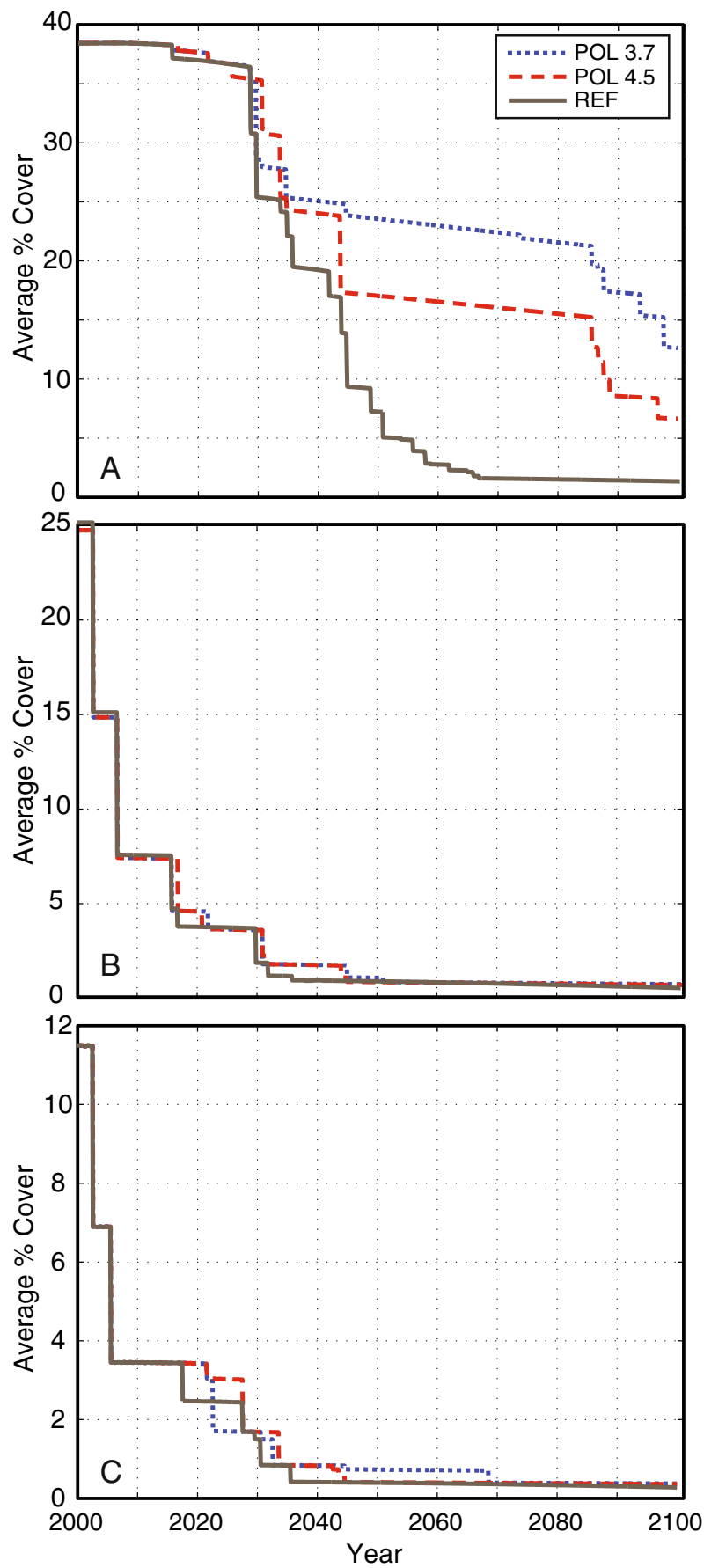

Fig. 3 Projected change in coral cover from 2000 to 2100 for three locations and three climate scenarios (REF, POL3.7, and POL4.5). a Hawaii, b Puerto Rico, c Florida 


\section{Discussion}

\subsection{Fisheries}

At a national scale, increasing stream temperatures over the 21 st century in the absence of GHG mitigation policies are likely to transform habitat currently suitable for coldwater fish into areas only suitable for less recreationally desirable warmwater species. Specifically, the projected loss of coldwater habitat by 2100 under the REF scenario is about 440,000 acres, a reduction of $62 \%$ of the estimated area of coldwater habitat in 2000 in the coterminous U.S. Within discrete regions, the same thermal disruption is likely to transform areas currently suitable for warmwater species into habitat only suitable for undesirable rough species. Overall, our analysis suggests that these shifts could generate considerable national-scale economic losses associated with a decreased value of recreational fisheries. Finally, the relatively "wet" climate simulations from the IGSM-CAM estimate changes in flow that have only a small impact on the trend and magnitude of these shifts. ${ }^{6}$

We project that the POL3.7 and POL4.5 scenarios would mitigate many of the habitat changes and economic losses associated with the REF scenario. For example, the projected loss of coldwater habitat by 2100 under the POL3.7 scenario is about 85,000 acres, which is a reduction of $12 \%$ of the estimated area of coldwater habitat in 2000. On a regional basis, coldwater fisheries are projected to be maintained in Appalachia and large areas of the Rocky Mountains in 2100 under the GHG mitigation scenarios, resulting in economic benefits; this coldwater habitat is lost in all of Appalachia and large portions of the Rockies under the REF scenario. Overall economic benefits associated with implementation of the GHG mitigation scenarios are lower for all fisheries compared to just coldwater fisheries because the expansion of warmwater fishing under the REF scenario offsets some of the coldwater losses.

Comparison of these results to the findings in Jones et al. (2012) is instructive because identical biophysical and habitat modeling methods are used for both analyses, but the studies differ in the GHG emissions scenarios and climate projections used. ${ }^{7}$ In this study, we show a national decline of coldwater habitat of approximately $62 \%$ by 2100 under the REF scenario, which is comparable to the $56 \%$ decline for the high emissions scenario in Jones et al. (2012). ${ }^{8}$ The coldwater habitat projections differ more between studies for the lower-bound GHG emissions scenarios: $40 \%$ reduction for SRES-B1 in Jones et al. (2012) compared to 11 and $12 \%$ reductions in the current paper for POL4.5 and POL3.7, respectively.

The main reason for the difference between the findings of these two analyses is that Jones et al. (2012) used climate data from an ensemble of ten GCM patterns, while this study relied primarily on output from a single GCM, the IGSM-CAM. By averaging across ten GCM patterns, the climate projections applied in Jones et al. (2012) likely reduced inter-annual variability and underestimated natural climate variability and weather extreme events [see Monier et al. (2014, this issue), for a discussion of differences between the IGSM-CAM and

\footnotetext{
${ }^{6}$ This study does not specifically account for stream temperature and flow interactions. Increased flow could mitigate temperature increases, while decreased flow could exacerbate increases. These interactions could affect suitability for fish guilds if projected water temperatures are close to thresholds.

${ }^{7}$ Due to space constraints, the reader is referred to Jones et al. (2012) for a detailed comparison of modeling results to previously published studies.

${ }^{8}$ The lower-bound SRES-B1 GHG emissions scenario in Jones et al. (2012) has a similar global mean temperature increase by 2100 as the POL4.5 $\left(4.5 \mathrm{~W} / \mathrm{m}^{2}\right)$ scenario, both approximately $2{ }^{\circ} \mathrm{C}$; the upper-bound A1FI scenario in Jones et al. (2012) and the REF scenario both indicate a global mean temperature increase of approximately $5{ }^{\circ} \mathrm{C}$. See Paltsev et al. (2014, this issue) and Waldhoff et al. (2014, this issue) for more scenario comparison details.
} 
pattern-scaled projections]. Compared to the ensemble mean approach, the IGSM-CAM projections include more frequent and intense climate extremes (e.g., heat waves) that have implications for the habitat suitability of coldwater species. The effects of these extremes on suitable habitat are most apparent in the low GHG emissions scenarios where key ecosystem thresholds have not been exceeded, i.e., under the high GHG scenarios, much of the coldwater habitat has already transformed to warmer guilds and the extreme events have less impact.

\subsection{Coral reef modeling}

Across the three key regions for U.S. coral reefs, the modeling results presented here suggest a different trajectory for South Florida and Puerto Rico compared to Hawaii. In South Florida and Puerto Rico, the projected GHG reductions associated with the two policy scenarios appear insufficient to avoid multiple bleaching and mortality events by 2020 . Multiple bleaching events within a short time period are projected to lead to coral reefs with a coral cover level likely too low to support local recruitment and the accumulation of endogenous carbonate (e.g., Harriott and Banks 2002). A recent study suggests that even in the absence of bleaching, intrinsic growth rates of coral in the Caribbean have slowed considerably compared to historical averages, further restricting the ability of corals to recover from bleaching and mortality events (Perry et al. 2013). Although the projected ecological and economic benefits of the policy scenarios appear slight for coral reefs in South Florida and Puerto Rico, it is certainly possible that lower SSTs and reduced ocean acidification associated with the GHG mitigation scenarios would provide benefits to localized areas of more resilient corals over the 21 st century.

The results are different for Hawaii, however, where there are cooler SSTs, greater coral cover, and more warming required to initiate bleaching. For Hawaii, the two GHG mitigation scenarios are projected to provide significant ecological benefits for coral reefs during the $21 \mathrm{st}$ century, delaying the extensive bleaching projected to occur by 2050 under the REF scenario. Even under the policy scenarios, however, there are still substantial reductions in coral cover by 2100 for Hawaii. The delay in the projected timing for bleaching events associated with the policy scenarios is associated with substantial economic benefits during the 21st century.

As with the comparison to Jones et al. (2012) above, identical biophysical and economic modeling methods are used for the analysis here and in Lane et al. (2013), but the studies differ in GHG emissions scenarios and climate projections. In this study, we show a decline in coral cover in Hawaii below $5 \%$ by approximately 2050 under the REF scenario, which is comparable to a decline below $5 \%$ by 2060 for the business-as-usual scenario in Lane et al. (2013). The coral cover projections for Hawaii by 2100 differ more between studies for the lower-bound GHG emissions scenarios: 22\% coral cover remaining in 2100 for the reduced emissions scenario (comparable to SRES-B1) in Lane et al. (2013) compared to approximately $12 \%$ remaining coral cover for the POL3.7 scenario.

\section{Conclusion}

The results of this study are consistent with those found in previous literature that both coldwater fisheries and coral reefs are highly vulnerable to climate change; however, the adoption of global policies that reduce GHG emissions can mitigate some of the projected biological and economic impacts. Both the fisheries and coral reef analyses incorporate threshold conditions into the modeling associated with crossing thermal thresholds. For the 
fisheries modeling, there are irreversible changes associated with the transition from coldwater to warmwater fisheries and from warmwater to rough fisheries, once thermal threshold values are crossed. Similarly, for the coral reef modeling, crossing bleaching thresholds results in significant mortality and losses of coral cover that cannot be overcome by coral growth inbetween bleaching events.

The estimates of consumer surplus used in the analyses incorporate current substitute activities. It is impossible, however, to predict how individuals in the future will value coldwater fishing and coral reef recreation, as these habitats are projected to become more rare and degraded. Within the limitations and uncertainties of this analysis, a global GHG mitigation policy that significantly reduces GHG emissions (e.g., POL3.7) would be associated with protecting economic benefits (compared to a REF scenario) of approximately $\$ 1.2$ billion for coldwater fishing only and $\$ 320$ million $^{9}$ when all freshwater fishing in rivers and streams is considered, and approximately $\$ 18.8$ billion (range of $\$ 9.8-28$ billion) for coral reef recreation over the 21 st century. The results of this paper are meaningful because they show how benefits of GHG mitigation change under increasingly stringent mitigation scenarios relative to a REF scenario. These quantified economic benefits, associated solely with widely measured recreational uses, are a subset of the total economic and societal benefits associated with policies that mitigate GHGs to avoid or delay projected future declines in freshwater fisheries and coral reefs.

Acknowledgments The authors wish to acknowledge the U.S. Environmental Protection Agency's (USEPA's) Climate Change Division for funding this analysis (Contract EP-BPA-12-H-0024). We also thank the additional members of our research team: Susan Humphries (formerly of Stratus Consulting) for her help in establishing maximum weekly average temperature values for each fish guild, and Dr. Karen Carney (Stratus Consulting) for general technical and editorial input to our analyses and paper. The views expressed in this document are solely those of the authors and do not necessarily reflect those of USEPA.

Open Access This article is distributed under the terms of the Creative Commons Attribution License which permits any use, distribution, and reproduction in any medium, provided the original author(s) and the source are credited.

\section{References}

Allen PM, Arnold JG, Byars BW (1994) Downstream channel geometry for use in planning-level models. J Water Resour Bull 30(4):63-671

Bates BC, Kundzewicz ZW, Wu S, Palutikof JP (eds) (2008) Climate change and water. Technical Paper of the Intergovernmental Panel on Climate Change, IPCC Secretariat, Geneva, Switzerland

Bhat MG (2003) Application of non-market valuation to the Florida keys marine reserve management. J Environ Manag 67(4):315-325

Buddemeier RW, Jokiel PL, Zimmerman KM, Lane DR, Carey JM, Bohling GC, Martinich JA (2008) A modeling tool to evaluate regional coral reef responses to changes in climate and ocean chemistry. Limnol Oceanogr Methods 6:395-411

Buddemeier R, Lane D, Martinich J (2011) Modeling regional coral reef responses to global warming and changes in ocean chemistry: Caribbean case study. Clim Chang. doi:10.1007/s10584-011-0022-z

Cesar H, van Beukering P, Pintz S, Dierking S (2002) Economic valuation of the coral reefs of Hawaii. Final report. Hawaii Coral Reef Initiative Research Program

\footnotetext{
${ }^{9}$ Note that the projected economic loss associated with coldwater fishing only is greater than the projected economic loss when all types of fishing are considered because the model assumes that anglers will substitute warmwater fishing for coldwater fishing, as coldwater fishing is lost.
} 
Donner SD (2009) Coping with commitment: projected thermal stress on coral reefs under different future scenarios. PLoS ONE 4(6):e5712. doi:10.1371/journal.pone.0005712

Dunne T, Leopold L (1978) Water in environmental planning. W.H. Freeman and Company, San Francisco

Eaton JG, Scheller RM (1996) Effects of climate warming on fish thermal habitat in streams of the United States. Limnol Oceanogr 41:1109-1115

Eaton JG, McCormick JH, Goodno BE, O’Brien DG, Stefan HG, Hondzo M, Scheller RM (1995) A field information-based system for estimating fish temperature tolerances. Fisheries 20:10-18

Estudios Técnicos (2007) Valoración económica de los arrecifes de coral y ambientes asociados en el este de Puerto Rico: Fajardo, arrecifes la cordillera, vieques y culebra. Estudios Técnicos Inc. Informe Final DRNA/ NOAA

Gössling S, Bredberg M, Randow A, Sandström E, Svensson P (2006) Tourist perceptions of climate change: a study of international tourists in Zanzibar. Curr Issues Tour 9:419-435

Gössling S, Scott D, Hall CM, Ceron JP, Dubois G (2012) Consumer behaviour and demand response of tourists to climate change. Ann Tour Res 39(1):36-58

Harriott VJ, Banks SA (2002) Latitudinal variation in coral communities in eastern Australia: a qualitative biophysical model of factors regulating coral reefs. Coral Reefs 21:83-94

Hoegh-Guldberg O, Mumby PJ, Hooten AJ, Steneck RS, Greenfield P, Gomez E, Harvell CD, Sale PF, Edwards AJ, Caldeira K, Knowlton N, Eakin CM, Iglesias-Prieto R, Muthiga N, Bradbury RH, Dubi A, Hatziolos ME (2007) Coral reefs under rapid climate change and ocean acidification. Science 318:1737-1744

Johns GM, Leeworthy VR, Bell FW, Bonn MA (2001) Socioeconomic study of reefs in Southeast Florida. Final report. Hazen and Sawyer Environmental Engineers \& Scientists

Jones RW, Travers C, Rodgers C, Lazar B, English E, Lipton J, Vogel J, Strzepek K, Martinich J (2012) Climate change impacts on freshwater recreational fishing in the United States. Mitig Adapt Strateg Glob Chang. doi: 10.1007/s11027-012-9385-3

Kragt ME, Roebeling PC, Ruijs A (2009) Effects of Great Barrier Reef degradation on recreational reef-trip demand: a contingent behaviour approach. Aust J Agric Resour Econ 53:213-229

Lane DR, Ready RC, Buddemeier RW, Martinich JA, Shouse KC, Wobus CW (2013) Quantifying and valuing potential climate change impacts on coral reefs in the United States: comparison of two scenarios. PLoS ONE 8(12):e82579. doi:10.1371/journal.pone.0082579

Londono-Diaz L, Johnston RJ (2012) Enhancing the reliability of benefit transfer over heterogeneous sites: A meta-analysis of international coral reef values. Ecol Econ 78:80-89. doi:10.1016/j.ecolecon.2012.03.016

Monier E, Gao X, Scott J, Sokolov A, Schlosser A (2014) A framework for modeling uncertainty in regional climate change. Clim Chang. doi:10.1007/s10584-014-1112-5 (this issue)

Paltsev S, Monier E, Scott J, Sokolov A, Reilly J (2014) Integrated economic and climate projections for impact assessment. Clim Chang. doi:10.1007/s10584-013-0892-3 (this issue)

Perry CT, Murphy GN, Kench PS, Smithers SG, Edinger EN, Steneck RS, Mumby PJ (2013) Caribbean-wide decline in carbonate production threatens coral reef growth. Nat Commun. doi:10.1038/ncomms2409, Published online January 29, 2013

Russell CS, Vaughan WJ (1982) The national recreational fishing benefits of water pollution control. J Environ Econ Manag 9:328-354

Shrestha RK, Loomis JB (2001) Testing a meta-model for benefit transfer in international outdoor recreation. Ecol Econ 39(1):67-83

Smith SV, Buddemeier RW (1992) Global change and coral reef ecosystems. Annu Rev Ecol Syst 23:89-118

Smith WHF, Sandwell DT (1997) Global seafloor topography from satellite altimetry and ship depth soundings. Science 277:1957-1962

Strzepek K, Neumann J, Smith J, Martinich J, Boehlert B, Hejazi M, Henderson J, Wobus C, Jones R, Calvin K, Johnson D, Monier E, Strzepek J, Yoon JH (2014) Benefits of greenhouse gas mitigation on the supply, management, and use of water resources in the United States. Clim Chang (this issue)

Tonn W (1990) Climate change and fish communities: a conceptual framework. Trans Am Fish Soc 119:337352

Vaughan WJ, Russell CS (1982) Valuing a fishing day: an application of a systematic varying parameter model. Land Econ 58:450-463

Waldhoff S, Martinich J, Sarofim M, DeAngelo B, McFarland J, Jantarasami L, Shouse K, Crimmins A, Li J (2014) Overview of the Special Issue: a multi-model framework to achieve consistent evaluation of climate change impacts in the United States. Clim Chang (this issue) 